\title{
The Nuclear Arms Race: Prisoner's Dilemma or Perceptual Dilemma?*
}

\author{
S. PLOUS \\ Department of Psychology, Wesleyan University
}

\begin{abstract}
Traditionally, the most common game-theoretic model of the Soviet-US nuclear arms race has been an iterated Prisoner's Dilemma. According to such a model, on any given trial both superpowers are better off arming regardless of what the other side chooses, but if both sides arm the outcome is less desirable than had both sides reduced their supply of weapons. Although Soviet and US preferences resembled a Prisoner's Dilemma throughout much of the Cold War, recent evidence suggests that the arms race is now more accurately modeled by a 'Perceptual Dilemma'. In a Perceptual Dilemma, both sides: (1) prefer mutual arms reductions to all other outcomes; (2) want above all to avoid disarming while the other side arms; and (3) perceive the other side as preferring unilateral armament to all other outcomes. This article presents empirical evidence that the nuclear arms race is more appropriately modeled by a Perceptual Dilemma than by a Prisoner's Dilemma, including new survey data in which members of the Australian Parliament and the Israeli Knesset were asked to estimate the preferences of Soviet and US leaders. The paper concludes by reviewing several factors which sustain misperception and by suggesting that a Perceptual Dilemma can be solved with a clear, time-limited series of disarmament initiatives.
\end{abstract}

A great deal in the development of relations between the USSR and the US depends on how each of the sides perceives the world.

Mikhail Gorbachev, 22 November 1985

\section{Background}

The 1980s: No decade in the history of Soviet-US relations ended so differently than it began. Gone were US pronouncements about 'the focus of evil in the modern world'. Gone were Soviet pronouncements about 'imperialist aggressors'. By the close of 1989, George Bush had remarked of Mikhail Gorbachev, 'You get the feeling he really wants to work with us', and by 1990 the United States and the Soviet Union had joined in a military coalition to oppose the Iraqi takeover of Kuwait. The wheel had nearly turned full circle.

Although these changes are of immense political and economic importance, their most profound significance rests in how they have transformed the nuclear arms race between the superpowers. It is this transformation - from bitter conflict to tentative coop-

\footnotetext{
* I wish to thank Kim Bartholomew, Diane Ersepke, Nancy Kanwisher, and Elke Weber for their comments on an earlier draft.
}

eration - which constitutes the focus of the present paper.

From the 1960s onward, the most popular game-theoretic model of the Soviet-US nuclear arms race has been the iterated Prisoner's Dilemma (Brams, 1985, p. 88). Hundreds of studies have been conducted on the Prisoner's Dilemma and its variants, often as an explicit analogue to superpower conflict. Typically, the United States and the Soviet Union ${ }^{1}$ are cast in a $2 \times 2$ game with one of four outcomes possible on each trial: mutual arms reductions, US armament and Soviet reductions, Soviet armament and US reductions, or a buildup of nuclear weapons on both sides. In most cases, more specific outcomes - such as the deployment of one weapon and removal of another - are excluded for purposes of analysis. ${ }^{2}$

According to a Prisoner's Dilemma, voth sides ideally prefer to arm while the other disarms. In fact, on any given trial both sides are better off arming regardless of what the other side chooses to do. If, for example, the Soviet Union chooses to reduce its stockpile, then US armament will secure the outcome most preferred by the United States (unilateral US armament). If, on the other hand, the Soviet Union chooses 
to arm, then US armament will at least prevent the outcome most feared by the United States (unilateral US reductions). The dilemma is that if both sides choose to arm, neither will be as well off as if they had both chosen to cooperate (see Table I).

Table I. A Prisoner's Dilemma

\begin{tabular}{llcc}
\hline & & & USSR \\
& & Disarm & Arm \\
\hline \multirow{2}{*}{ US } & Disarm & 3,3 & 1,4 \\
\cline { 3 - 4 } Arm & 4,1 & 2,2 \\
\hline
\end{tabular}

This matrix contains an ordinal representation of the preferences found in a Prisoner's Dilemma. As is customary in game theory, the first number in each cell represents how desirable that outcome is for Row (in this case, the US), and the second number represents how desirable the same outcome is for Column (the USSR). The most preferred outcome is indicated with a ' 4 ', and the least preferred outcome is indicated with a ' 1 '. In a Prisoner's Dilemma, both sides ideally prefer to arm while the other side disarms.

Notwithstanding the inherent limitations of any game-theoretic approach, the Prisoner's Dilemma is a reasonable model of superpower conflict and has been adopted by many leading game theorists. For example, in their innovative work Game Theory and National Security, Brams \& Kilgour stated that 'the arms race has persisted, we believe, because both sides see it as a Prisoner's Dilemma' (1988, p. 30). Similarly, Hardin $(1983$, p. 248$)$ argued that the Prisoner's Dilemma 'represents the preference ordering of virtually all articulate policy makers and policy analysts in the United States and presumably also in the Soviet Union'. Nor are these scholars alone in this belief. Research on the Prisoner's Dilemma has been sponsored by the United States Arms Control and Disarmament Agency (Lindskold et al., 1972; Shubik, 1968), the United States Air Force (Scodel, 1962), and the Office of Naval Research (Deutsch et al., 1967; Luce \& Adams, 1956; Pruitt, 1967, 1970). It has also involved researchers at the International Peace Research Institute in Oslo (Lumsden, 1966, 1973) and the British Ministry of Defence and Department of Atomic Energy (Brew, 1973).

Although the historical record is far from clear, there is reason to believe that the Soviet-US nuclear arms race conformed to a Prisoner's Dilemma throughout much of the Cold War era. Both superpowers openly pursued the goal of nuclear superiority (see Table II), and neither side moderated its behavior in response to cooperative initiatives made by the other side.

By the early- to mid-1980s, however, many US and Soviet political leaders began to perceive the utility of mutual arms reductions as greater than that of unilateral armament, whether for military, political, economic, moral, or other reasons. Spurred by a change in Soviet leadership and by the emergence of a worldwide anti-nuclear movement, many political leaders questioned the value - and indeed, the meaning - of 'nuclear superiority'. For example, in 1982 Nikolai N. Inozemtsev, Director of the Soviet Institute of World Economy and International Relations, observed that: 'Political and military doctrines have been changed. This has been reflected in our internal life. There is a new determination to seek [arms] reductions' (Beres, 1982, p. 10). This change was equally apparent in the official declaratory policy of the Soviet Union. As early as 1985, Mikhail Gorbachev stated that: 'Lessened security for the United States of America in comparison with the Soviet Union would be disadvantageous to us, since it would lead to mistrust and would engender instability' (Gorbachev, 1985 , p. 1). Though less pronounced, similar changes took place on the US side. As one member of the US START delegation remarked in 1986: 'Both sides are now committed to deep reductions. You could not have said that two years ago' (Ifft, 1986).

Of course, public declarations need not reflect operational policies. There are many instances in which such statements are strictly propagandistic, and it is quite possible that these changes merely reflect a change in political rhetoric. Yet several lines of evidence suggest that in this case, US and Soviet statements concerning the nuclear 
Table II. Statements Suggesting That the Nuclear Arms Race Was Once a Prisoner's Dilemma

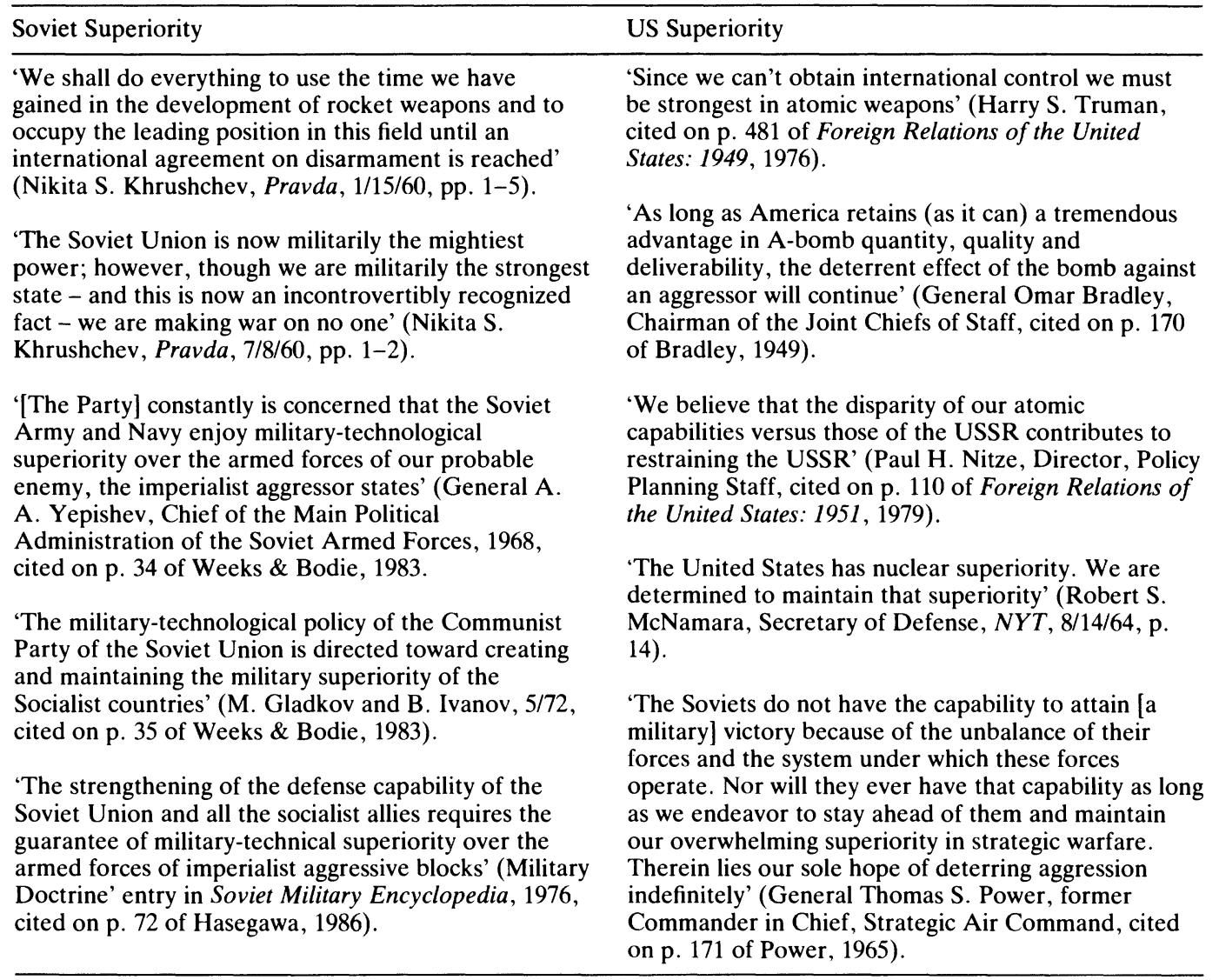

Soviet statements are taken from Current Digest of the Soviet Press, unless otherwise noted. Political offices listed were those held at the time statements were made.

arms race are probably not at great variance with the true objectives pursued by each government. First, policy statements intended for public or foreign consumption have tended to be consistent with statements intended for private or domestic audiences (Frei, 1986; Halloran, 1988; Jackson, 1981; MccGwire, 1987; McConnell, 1985). Second, content analyses have often found a significant correspondence between public declarations and superpower behavior (Axelrod \& Zimmerman, 1981; Hermann, 1980; Tetlock, 1985; Zimmerman \& Palmer, 1983). Third, former government officials have attested to the authenticity of public declarations. For example, Kenneth Adelman, former director of the Arms
Control and Disarmament Agency, has stated that: 'We say to the Soviets just about exactly what we say in public. If you look at the public documents and statements you will know what is happening in private' (Deadline, 1988, p. 4). Although such evidence is not conclusive, it suggests that a genuine shift in US and Soviet policy is at least plausible. As Bennett \& Dando (1983, p. 434) have said: 'Each side claims to want mutual disarmament most of all, and claims, furthermore, that only the aggressiveness of the other side prevents this. We would be the last to advocate wholesale belief in the utterances of governments, but it is at least possible that these protestations are sincere.' 


\section{An Alternative Model: The Perceptual Dilemma}

If Soviet and US policy preferences have truly undergone a transformation, how can the nuclear arms race be modeled to take these changes into account? Is there a more accurate model than the Prisoner's Dilemma? Within the constraints of a static $2 \times 2$ game, one viable alternative is what I have called a 'Perceptual Dilemma' (Plous, 1985, 1987, 1988). In a Perceptual Dilemma, the prevailing leaders in both superpowers: (1) prefer arms reductions to all other outcomes, (2) want above all to avoid disarming while the other side arms and (3) perceive the other side as most preferring unilateral armament. Because each side believes that its own disarmament is an invitation for the other side to arm - even though both actually prefer arms reductions - the result is an arms race. Moreover, because neither side has a desire to arm, both interpret the arms race as confirming evidence that the other side wishes to arm (cf. Jervis, 1976).

The Perceptual Dilemma differs from the Prisoner's Dilemma in several critical respects. Unlike the Prisoner's Dilemma, in which both sides ideally prefer unilateral armament, each party in a Perceptual Dilemma prefers arms reductions to all other outcomes, but is prevented from disarming by the perception that the other side favors unilateral armament. In game-theoretic terms, this perception is modeled by granting each party a separate payoff matrix that contains preferences for itself and preferences perceived to be held by the other side. It is only by joining these two matrices, or halves, that a Perceptual Dilemma is formed.

In contrast to the iterated Prisoner's Dilemma, which has no stable solution and has a dominating strategy to arm, a Perceptual Dilemma can be solved when either side persuades the other that it truly desires mutual reductions more than unilateral armament. For example, if Soviet leaders were convinced that the 'payoffs' in Table III represented US preferences, and if they viewed mutual arms reductions as more desirable than unilateral armament, little reason would remain to continue the nuclear arms race. In a Perceptual Dilemma, the key question is how to convince each side of the other's true preferences.

Table III. The American Half of a Perceptual Dilemma

\begin{tabular}{cccc}
\hline & & & USSR \\
& & Disarm & Arm \\
\hline \multirow{2}{*}{ US Disarm } & $8,[6]$ & $-7,[7]$ \\
\cline { 3 - 4 } & Arm & $1,[-7]$ & $-5,[-1]$ \\
\hline
\end{tabular}

These numbers represent the mean desirability ratings provided by 32 US senators. The first number in each cell indicates how desirable the outcome is for the United States, and the bracketed number indicates the senators' perceptions of how desirable Soviet leaders would rate the outcome to be. Higher numbers indicate greater desirability.

\subsection{The US Half of a Perceptual Dilemma}

Rather than initially assessing the policy preferences held by each party to a conflict and later studying the obtained preference structure, virtually all game research begins by assuming that a particular preference structure represents a given conflict. A recent review of empirical game research yielded only one published account in which the participants in a conflict were directly surveyed about the desirability of various options (Plous, 1985). During the Cyprus conflict, Lumsden (1973) asked 134 Greek Cypriot and 51 Turkish Cypriot student teachers to evaluate the desirability of jointly modifying their positions, jointly maintaining their positions, modifying only the Greek position, or modifying only the Turkish position. Although student teachers were obviously not ideal respondents, Lumsden's work is important for two reasons. First, it demonstrates the feasibility of assessing policy preferences and then fitting an appropriate game-theoretic model to a particular conflict. Second, the preferences Lumsden found corresponded to a Prisoner's Dilemma, lending support to Prisoner's Dilemma as a valid model of naturally occurring conflict.

No method of assessing policy prefer- 
ences is entirely adequate, but each, in its own way, can be very informative. As part of an effort to determine US and Soviet preferences concerning the nuclear arms race, I conducted a mail survey several years ago in which United States' senators were asked to rate the desirability of four options: (a) a continuation of the nuclear arms race, (b) mutual nuclear arms reductions, (c) armament by the Soviet Union and reductions by the United States, and (d) reductions by the Soviet Union and armament by the United States (for details, see Plous, 1985). The scale ranged from a minimum of ' -10 ' (worst possible consequences) to a maximum of ' +10 ' (best consequences imaginable), with ' 0 ' as the midpoint (consequences neither good nor bad). Once senators rated the four options for the United States, they attempted to take the perspective of Soviet leaders estimating the desirability of the same four alternatives for the Soviet Union.

Thirty-two senators completed the survey, and their average responses are summarized in Table III. As can be seen, the game matrix corresponds perfectly to the US half of a Perceptual Dilemma. In fact, senators judged unilateral armament by the United States as only marginally positive. Mutual arms reductions, with an average rating seven scale points higher than unilateral armament, was viewed as the most desirable alternative. Unlike the United States, however, the Soviet Union was perceived as desiring unilateral armament more than any other outcome. Of the senators who responded, $66 \%$ believed that unilateral armament was the first choice of the Soviet leadership, $72 \%$ felt that US unilateral reductions would be the worst outcome for the United States, and $81 \%$ saw mutual reductions as the most desirable outcome for the United States. Contrary to the historical assumptions of game research, not a single senator evaluated the nuclear arms race as a Prisoner's Dilemma.

Such results are consistent with political statements made by George Bush. For example, in 1989 he declared that:

Soviet military power far exceeds the levels needed to defend the legitimate security interests of the USSR. . . . The purpose of our military might is not to pressure a weak Soviet economy, or to seek military superiority. It is to deter war. . . . We seek verifiable, stabilizing arms control and arms reduction agreements with the Soviet Union and its allies (italics added; 'Excerpts', 25 May 1989; 'Transcript', 13 May 1989).

\subsection{The Soviet Half of a Percéptual \\ Dilemma}

Although direct Soviet survey data are unavailable,$^{3}$ 'surrogate' studies of Soviet opinion, undertaken by the United States International Communication Agency, provide support for the Soviet half of a Perceptual Dilemma (Guroff \& Grant, 1981). In these surveys, a large number of US citizens and Western Europeans who had close ties to Soviet political elites were asked to answer questions as their Soviet counterparts would. Despite certain drawbacks in this methodology, a surrogate approach has the advantage of easing social demand characteristics, and in many cases the respondents were nearly unanimous in opinion. According to Guroff \& Grant (1981, p. 16), the results indicated that: (1) Soviet leaders viewed arms control as 'logical, even imperative'; (2) 'Soviets say that they will never allow the United States to gain outright military superiority over them again, that they will make whatever sacrifices are necessary to prevent this'; and (3) 'Soviet elites find it difficult to interpret proposed massive new arms expenditures in the United States as other than attempts to, first, gain military superiority and, second, drive the Soviet economy to bankruptcy'. In other words, Soviet preferences closely resembled a Perceptual Dilemma.

As shown in Tables IV, V, and VI, the three components of a Perceptual Dilemma are also clearly articulated in Soviet declaratory policy. All Soviet statements which appear in these tables are taken from the years when Ronald Reagan was president of the United States, and a small sample of contemporaneous US declarations is included at the back of each table for 
Table IV. Statements Suggesting That Mutual Reductions Are Most Favored

Statements by the Soviet General Secretary

'The Soviet Union - and we stress this anew - does not seek military superiority. . . The Soviet Union states, in no uncertain terms and as firmly as possible, that it remains attached to a principled course aimed at ending the arms race - above all, the nuclear arms race' (Yuri V. Andropov, Pravda, 11/25/83, p. 1).

'We have been and remain convinced advocates of halting the arms race and reversing it. The whole set of proposals advanced by the Soviet Union is directed to this end' (Konstantin U. Chernenko, Pravda, 4/9/84, pp. $1-2)$.

'The only reasonable way out of the existing situation is agreement of the confronting forces on an immediate termination of the race in arms, above all, nuclear arms. . . . We do not strive to acquire unilateral advantages over the United States, over NATO countries, for military superiority over them; we want termination, not continuation of the arms race' (Mikhail S. Gorbachev, NYT, 3/12/85, p. 6).

\section{Other Soviet Statements}

'The very sense of our doctrine and of our policy is not a course towards military superiority, but a policy towards arms control, disarmament, and a slackening of military confrontation' (Marshall Sergei Akhromeyev, Pravda, 5/18/83, pp. 1-4).

'The Soviet Union remains attached to its principled course aimed at ending the arms race, above all the nuclear arms race' (Marshall N. V. Ogarkov, First Deputy of Defense, Pravda, 12/6/83, p. 4).

'It is necessary above all to abandon attempts to upset the existing military-strategic equilibrium, to stop the buildup of nuclear arms, and to undertake efforts to limit and reduce these arms' (Andrei A. Gromyko, Foreign Minister, Pravda, 2/15/84, p. 2).

'We are engaged in a constructive search for mutually acceptable practical solutions and do not seek unilateral benefits, military advantages for ourselves' (Victor Karpov, Chief, Arms Limitation and Disarmament Division, Ministry of Foreign Affairs, New Times, 7/21/86, pp. 4-5).

'The USSR does not want an arms race. The Soviet Union resolutely stands for halting competition in the military field and for a radical reduction in the level of nuclear confrontation' (Alexei Platonov, Arms Control Analyst, cited on p. 37 of Platonov, 1986).

\section{Statements by the US President}

'We want more than anything else to join with them in reducing the number of weapons' (Ronald W. Reagan, $N Y T, 6 / 15 / 84$, p. 8).

'We want to develop a more realistic working relationship with the Soviet Union, one marked by greater cooperation and understanding and by progress in arms reductions' (Ronald W. Reagan, $N Y T, 6 / 22 / 84$, p. 3).

\section{Other US Statements}

'What we should be doing is reducing the number of nuclear weapons and their destructive capability' (George P. Shultz, Secretary of State, $N Y T, 1 / 18 / 84$, pp. A1, A4).

'We have consistently taken the position that reducing nuclear weapons must be the most important objective facing both countries' (Robert C. McFarlane, National Security Advisor, $N Y T, 11 / 23 / 84$, p. A6).

Soviet statements are taken from Current Digest of the Soviet Press, unless otherwise noted. NYT denotes New York Times. Political offices listed were those held at the time statements were made.

purposes of comparison. Each table begins with statements by the General Secretary of the Soviet Union (i.e. Yuri Andropov, Konstantin Chernenko, or Mikhail Gorbachev) and continues with statements made by foreign and defense ministers and deputies, high-ranking political advisors, and assorted commentators. Although the statements do 
Table V. Statements Suggesting That Unilateral Reductions Are Least Favored

Statements by the Soviet General Secretary

'All attempts to achieve military superiority over the USSR will be unavailing. The Soviet Union will never allow this' (Yuri V. Andropov, Pravda, 3/27/83, p. 1).

'Our country does not seek [nuclear] superiority, but it also will not allow superiority to be gained over it' (Konstantin U. Chernenko, Pravda, 4/9/84, pp. 1-2).

'We will in no event allow the US to obtain military superiority over us' (Mikhail S. Gorbachev, 11/22/85, Pravda, p. 1).

'The Soviet Union lays no claim to greater security than that enjoyed by others, but it will not settle for less' (Mikhail S. Gorbachev, New Times, 3/10/86, pp. 35-40).

\section{Other Soviet Statements}

'The Warsaw Treaty countries have not sought and do not now seek to gain military superiority [but] in no event will they allow anyone to gain military superiority over them' (Communique on the Extraordinary Meeting of the Committee of Defense Ministers of the Warsaw Treaty Member-States, Pravda, 10/22/82, p. 4).

'We have repeatedly stated that the arms race is not our goal. But the Soviet Union has been compelled to take the necessary steps to prevent the imperialists from gaining advantages that would allow them to dictate conditions in their favor' (Marshal Dmitri F. Ustinov, Minister of Defense, Pravda, 4/7/83, p. 4).

'The Soviet Union does not want to have greater security than other countries but it will not agree to lesser security either' (Vadim Zagladin, First Deputy Chief of the International Department of the CPSU Central Committee, cited on p. 60 of Zagladin, 1986).

'The USSR will not allow any US superiority' (Genrikh Trofimenko, Chief, Foreign Policy Department, Institute of US and Canada Studies, cited on p. 174 of Trofimenko, 1986).

\section{Statements by the US President}

'My administration, our country, and I are committed to achieving arms reduction agreements . . But we cannot reduce arms unilaterally' (Ronald W. Reagan, NYT, 11/19/81, p. A17).

'We refuse to become weaker while potential adversaries remain committed to their imperialist adventures' (Ronald W. Reagan, NYT, 6/18/82, p. A16).

\section{Other US Statements}

'Nothing less than equality is acceptable in the provisions of any future strategic arms limitation agreement' (Alexander Haig, Secretary of State, $N Y T, 5 / 12 / 82$, p. A8).

'We are certainly not going to sit by quietly and do nothing while they develop the capability to fight, and - as they believe, apparently - to win what they call a protracted nuclear war' (Caspar Weinberger, 6/20/82, cited on p. 404 of Goldinger, 1983).

Soviet statements are taken from Current Digest of the Soviet Press, unless otherwise noted. NYT denotes New York Times. Political offices listed were those held at the time statements were made.

not constitute a random sample, their continuity over time and their consistency from person to person suggest that they accurately reflect the declaratory policy of the Soviet Union. Soviet officials have unambiguously stated that: (1) they prefer mutual nuclear arms reductions to any other alternative, (2) unilateral reductions are unacceptable, and (3) US leaders prefer unilateral armament. These positions have also been documented by several leading Sovietologists (cf. Bialer \& Afferica, 1982; Caldwell \& Legvold, 1983; Frei, 1986; Garthoff, 1978; Holloway, 1984; Talbott, 1984) and by 
Table VI. Statements Suggesting That Unilateral Armament Is Perceived as Most Favored by Other

Statement by the Soviet General Secretary

'The main obstacle - and the entire course of the Geneva talks is persuasive evidence of this - is the attempts by the US and its allies to achieve military superiority' (Yuri V. Andropov, Pravda, 1/13/84, p. 1).

\section{Other Soviet Statements}

'NATO [has] the aim of achieving military superiority for the NATO countries over the socialist and other countries of the world' (Declaration of the Warsaw Treaty Member States. Pravda, 11/24/78, pp. 1-3).

'The White House is openly pursuing a course aimed at the achievement of military superiority for the US over the USSR and for NATO bloc over the Warsaw Treaty Organization' (Marshal Dmitri F. Ustinov, Minister of Defense, Pravda, 11/19/83, p. 4).

'The US and a number of NATO countries are trying to eliminate the approximate equality of military forces, including nuclear forces, that exists in Europe' (L. M. Zamyatin, Director, Central Committee Department of International Information, Pravda, 12/6/83, p. 4).

'The international situation remains tense as a result of the course adopted by the US and the NATO bloc to achieve military superiority over the USSR and the Warsaw Treaty bloc' (B. Orekhov, Staff Correspondent, Pravda, 3/17/84, p. 4).

'The so-called rearming of America is nothing but a bid for strategic superiority' (Anatoly Dobrynin, Soviet Ambassador to the United States, Harper's, 7/85, p. 42).

'Under the guise of "deterrence" the US military-industrial complex has initiated programmes aimed at achieving superiority' (Alexei Platonov, Arms Control Analyst, cited on p. 20 of Platonov, 1986).

'As concerns nuclear weapons and their delivery systems (the principal field of the arms race), the United States pursues an extremely dangerous objective - that of attaining superiority' (Genrikh Trofimenko, Chief, Foreign Policy Department, Institute of US and Canada Studies, cited on p. 164 of Trofimenko, 1986).

\section{Statements by the US President}

'When we took office in 1981, the Soviet Union had been engaged for 20 years in the most massive military buildup in history. Clearly, their goal was not to catch us, but to surpass us' (Ronald W. Reagan, Weekly Compilation of Presidential Documents 20: 490-497).

'For the Soviet leaders peace is not the real issue; rather, the issue is the attempt to spread their dominance using military power' (Ronald W. Reagan, $N Y T, 6 / 28 / 84$, p. 8).

\section{Other US Statements}

'The Soviets are determined to hold the high ground of strategic superiority because their doctrine, unlike ours, is not focused at avoidance of war' (Major General George Keegan, Former Air Force Assistant Chief of Staff for Intelligence, cited on p. 69 of Daniel, 1978).

'The Soviet Union is still on the upswing of the historical cycle - of assertiveness, of expectations. I think it would like to be number one. I don't think it feels comfortable being number two militarily' (Zbigniew Brzezinski, Assistant to the President for National Security Affairs, Department of State Bulletin, 12/5/77, pp. 800-805).

'Moscow and Washington are not at loggerheads today because of misperception or misunderstanding ... The Soviet Union is shocked and even angered to find that the USA has reversed its course and will no longer accept efforts by the Soviet Union to achieve military advantage. It is for this reason that the Soviet Union walked out of the arms control talks' (Colin S. Gray, Member of the General Advisory Committee of the Arms Control and Disarmament Agency, USA Today, 6/15/84, p. 10A).

Soviet statements are taken from Current Digest of the Soviet Press, unless otherwise noted. NYT denotes New York Times. Political offices listed were those held at the time statements were made. 
Soviet writers who specialize in international security affairs (cf. Bykov, 1980; Lebedev, 1986; Luzin, 1981; Ponomarev, 1985; Trofimenko, 1986).

\section{New Evidence: A Survey of US Allies}

To date, the evidence in support of a Perceptual Dilemma has come primarily from US and Soviet sources. While it is true that any valid model of superpower conflict must accurately reflect the views of US and Soviet leaders, an exclusive reliance on US and Soviet sources leaves open the possibility that public statements in support of mutual arms reductions are motivated by political factors. Sources from other countries are not similarly motivated, however, and by using an approach analogous to the USICA surrogate technique, US and Soviet preferences can be estimated relatively free of demand characteristics.

In keeping with this logic, a mail survey of the Australian Parliament was conducted in late 1986. The Australian Parliament was chosen for several reasons: (1) Given that Australia is aligned with the United States, Australian perceptions concerning the Soviet desire for arms reductions would presumably provide a conservative estimate of true Soviet desires; (2) because Australia is not a member of the NATO alliance, Australian leaders would be relatively free to express their opinions concerning superpower objectives and the nuclear arms race; (3) by surveying parliament members rather than citizens, any differences with survey responses from the US Senate would not be attributable to discrepancies in 'mass' and 'elite' opinion; and (4) with 224 members, the Australian Parliament would be large enough to generate a statistically meaningful sample of respondents. ${ }^{4}$

Patterned after the earlier survey of the US Senate, the Australian survey began by asking respondents to rate four hypothetical alternatives from -10 to +10 in terms of how desirable they would be for Australia: (1) The USA and the USSR both make significant nuclear weapons reductions; (2) the USA makes significant nuclear weapons reductions and the USSR continues on its present course; (3) the USSR makes significant nuclear weapons reductions and the USA continues on its present course; and (4) the USA and the USSR both continue on their present course. The instructions emphasized that these options were necessarily oversimplified, but asked respondents to make their best judgement given such limitations. After respondents rated how desirable each of the four scenarios would be for Australia, they were then asked to 'answer the same four questions taking the perspective of US political leaders estimating the consequences for the United States'. Finally, respondents were asked to evaluate the alternatives from the perspective of Soviet political leaders.

Seventy-four of the 224 parliament members responded to the survey request. Of these 74 parliament members, 9 declined to participate or failed to provide adequate information, and 65 completed the survey form. Although a final return rate of $29 \%$ is ordinarily quite low, this level of return is typical for surveys of national leaders (cf. Plous, 1985). Moreover, demographics for the sample did not differ significantly from overall figures for the Parliament. Of the 61 respondents who provided demographic information, $52 \%$ were members of the Labor Party, exactly the same as the Parliament at large; $31 \%$ were members of the Liberal Party, compared with $33 \%$ of the entire Parliament; $8 \%$ were members of the National Party, compared with $12 \%$ in general; and $9 \%$ were Independents or Australian Democrats, compared with $4 \%$ of the total Parliament. Eighty-seven percent were male and $13 \%$ female, compared with $90 \%$ and $10 \%$ of the entire Parliament, and the mean age of respondents was 47 years $(\mathrm{SD}=7.9)$, compared with 49 years $(\mathrm{SD}=$ 8.7) for the Parliament as a whole. While these statistics alone cannot establish the sample as representative, the striking correspondence between sample and population on several different dimensions is certainly encouraging.

Table VII contains the mean desirability ratings for all 65 parliament members. ${ }^{5}$ As can be seen, respondents viewed mutual arms reductions as by far the most desirable 
Table VII. Australian Desirability Ratings for Nuclear Arms Race Alternatives

\begin{tabular}{cccc}
\hline & & & USSR \\
& & Disarm & Arm \\
\hline \multirow{2}{*}{ US } & Disarm & 7.4 & -3.5 \\
\cline { 3 - 4 } & Arm & 0.1 & -5.2 \\
\hline
\end{tabular}

Mean desirability ratings of arms race outcomes based on survey data from 65 members of the Australian Parliament. Higher numbers indicate greater desirability for Australia.

alternative for Australia $(M=+7.4)$. Respondents did not view unilateral US armament as a particularly positive alternative $(M=+0.1)$ and, perhaps surprisingly, actually rated unilateral reductions by the United States $(M=-3.5)$ as marginally more desirable than a continuation of the nuclear arms race $(M=-5.2 ; p=0.12$ by $t$ test). These findings coincide with the lack of Allied support for unilateral US armament found in public opinion polls in Great Britain, West Germany, France, and Italy (Daniel, 1978; Flynn \& Rattinger, 1985).

How did Australian Parliament members perceive US and Soviet preferences? As shown in Table VIII, Australian respondents saw the nuclear arms race not as US senators see it, but as the Soviet half of a Perceptual Dilemma. Although both superpowers were viewed as wanting above all to avoid unilateral reductions, only American leaders were seen as preferring unilateral armament $(M=+5.6)$ to mutual reductions $(M=+3.7 ; p<0.05$ by $t$-test $)$. Soviet leaders were not perceived as desiring unilateral armament $(M=+5.0)$ more than mutual arms reductions $(M=+5.5$; $n s$ by $t$ test). Compared with US leaders, Soviets were perceived as more desirous of mutual weapons reductions ( $p<0.01$ by $t$-test) and more opposed to a continuation of the arms race $(p<0.001$ by $t$-test $)$. In other words, the Australian model of superpower conflict depicted the United States as having a dominant strategy to arm and the Soviet Union as being forced to reciprocate.

These results are consistent with British, West German, and French polls showing that the Soviet Union is perceived as 'more
Table VIII. The Soviet-US Nuclear Arms Race As Seen by Members of the Australian Parliament

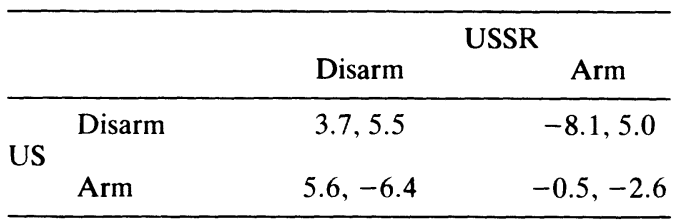

Numbers represent US and Soviet desirability ratings as perceived by 65 members of the Australian Parliament. The first number in each cell corresponds to Australian perceptions of how desirable the outcome is to US leaders, and the second number corresponds to perceptions of how desirable the outcome is to Soviet leaders. Higher numbers indicate greater perceived desirability.

concerned about the securing of peace and disarmament' and more deserving of credit for arms control progress than the United States (Gordon, 1987; Markham, 1987). At the same time, they clearly contradict several Dutch, German, and Italian polls from the early 1980 s in which respondents perceived both superpowers as bent on military superiority (Flynn \& Rattinger, 1985). Any of three explanations might account for this discrepancy: (1) It may be that Australia is not as close to the United States or as hostile to the Soviet Union as are other US allies; (2) it may be that the sample of Australian respondents is not representative of the Australian Parliament in general (normative comparisons with the Parliament were limited because the survey was strictly anonymous); or (3) it may be that Allied perceptions of US and Soviet objectives have actually changed since the time of the earlier public opinion polls.

In order to ensure that the Australian results were not a product of pro-Soviet or anti-US selection biases, the Australian survey was replicated with a US ally known for its profound distrust of Soviet leaders: Israel. Because Israel has had a bitter relationship with the Soviet Union since Brezhnev severed diplomatic ties in 1967, it is safe to assume that any biases on the part of Israeli leaders are in the direction of underestimating the Soviet desire for mutual weapons reductions and overestimating the Soviet desire for unilateral armament. Thus, if Israeli leaders perceive the 
Soviets as preferring mutual arms reductions to unilateral armament, there are strong grounds for believing that Soviet preferences do in fact conform to a Perceptual Dilemma.

During the summer of 1987 , a mail survey was sent to all 120 members of the Israeli Knesset. The Israeli survey was similar in format to the Australian survey, except that it was typeset in Hebrew and included a coding system on the back of each survey to allow for respondent identification (though the survey was not explicitly anonymous, respondents were not asked to identify themselves). ${ }^{6}$ Thirty-seven of the 120 Knesset members responded to the survey request: 3 declined to participate, 1 did not provide adequate information, and $33 \mathrm{com}$ pleted the survey form. Although a return rate of $28 \%$ is low by conventional standards, the sample appeared to be quite representative of the Knesset. For example, $41 \%$ of the respondents were members of the Likud Party, compared with $34 \%$ of the total Knesset; $41 \%$ were members of the Labor Party, compared with $33 \%$ of the entire Knesset; and 19\% were members of other parties, compared with $33 \%$ of the full Knesset. $^{7}$

Table IX contains the average desirability ratings for all 33 respondents. As in the case of the Australian Parliament, Knesset members viewed mutual arms reductions as the most desirable option $(M=+6.5)$, though they regarded unilateral Soviet reductions as almost as positive $(M=+4.8 ; p$ $=0.14$ by $t$-test). Knesset members also differed from Australian leaders in strongly preferring a continuation of the nuclear arms race $(M=-1.7)$ to unilateral US reductions $(M=-7.3 ; p=0.001$ by $t$-test $)$. These findings confirm that Israeli respondents were indeed more pro-US and/or antiSoviet than the Australian respondents.

Once again, however, Allied perceptions did not conform to the US half of a Perceptual Dilemma - or even to a Prisoner's Dilemma - but to the Soviet half of a Perceptual Dilemma. As shown in Table X, Israeli respondents viewed both superpowers as wanting above all to avoid unilateral arms reductions, but they saw only the
Soviet Union as desiring mutual reductions more than unilateral armament $(M=+6.8$ versus $M=+5.4$, though this difference did not reach statistical significance). Knesset members also perceived the Soviets as relatively more opposed to a continuation of the nuclear arms race $(M=-4.1$ versus $M=$ $-1.7 ; p<0.03$ by $t$-test) and slightly more desirous of mutual weapons reductions $(M$ $=+6.8$ versus $M=+5.2 ; p=0.13$ by $t$ test). Thus, in most respects the Israeli survey replicated the results found in the Australian survey.

In general, Australian and Israeli leaders perceived the nuclear arms race not as a Prisoner's Dilemma, but as the Soviet half of a Perceptual Dilemma. They tended to view Soviet leaders as preferring mutual weapons reductions and US leaders as preferring unilateral armament. Although advocates of the Prisoner's Dilemma might object that the present survey questions were so oversimplified as to be meaningless, it should be pointed out that the questions merely made explicit the logic which underpins game theory; to reject that logic is also to reject the Prisoner's Dilemma as a valid model of superpower conflict.

Proponents of the Prisoner's Dilemma might also claim that the Australian survey provided support for at least the US half of a Prisoner's Dilemma. While it is true that the Australian respondents perceived US leaders as preferring unilateral armament to mutual reductions, this support is undercut by survey data supplied directly from US senators and by the declarations contained in Tables IV, V, and VI. Furthermore, given the presumed tendency of Australian and Israeli leaders to underestimate the Soviet desire for mutual arms reductions and overestimate the Soviet desire for unilateral armament, it is unlikely that Soviet preferences conform to a Prisoner's Dilemma. Taken together with the evidence cited earlier, the present results suggest that Soviet preferences are more accurately reflected by a Perceptual Dilemma than by a Prisoner's Dilemma, and it remains for supporters of the Prisoner's Dilemma to furnish empirical evidence of its relevance to the nuclear arms race. ${ }^{8}$ 
Table IX. Israeli Desirability Ratings for Nuclear Arms Race Alternatives

\begin{tabular}{llcr}
\hline & & & USSR \\
& & Disarm & Arm \\
\hline \multirow{2}{*}{ US Disarm } & 6.5 & -7.3 \\
\cline { 3 - 4 } Arm & 4.8 & -1.7 \\
\hline
\end{tabular}

Mean desirability ratings based on survey data from 33 members of the Israeli Knesset. Higher numbers indicate greater desirability for Israel.

Table X. The Soviet-US Nuclear Arms Race As Seen by Members of the Knesset

\begin{tabular}{llcc}
\hline & & \multicolumn{2}{c}{ USSR } \\
\hline \multirow{2}{*}{ US } & Disarm & Disarm & Arm \\
\cline { 3 - 4 } Arm & $5.2,6.8$ & $-8.1,5.4$ \\
\hline
\end{tabular}

Numbers represent US and Soviet desirability ratings as perceived by 33 members of the Israeli Knesset. The first number in each cell corresponds to Israeli perceptions of how desirable the outcome is to US leaders, and the second number corresponds to perceptions of how desirable the outcome is to Soviet leaders. Higher numbers indicate greater perceived desirability.

\section{Factors That Sustain Misperception}

If the nuclear arms race is better modeled as a Perceptual Dilemma than as a Prisoner's Dilemma, why do misperceptions between the superpowers persist? There are several answers to this question. In the first place, a static $2 \times 2$ model such as the Perceptual Dilemma does not take into account the history of superpower conflict. If the Soviet-US nuclear arms race shifted from a Prisoner's Dilemma in the 1950s, 1960s, and 1970 s to a Perceptual Dilemma in the 1980 s, then a more comprehensive approach would be to model the arms race dynamically as a supergame.

Table XI depicts half of such a supergame. The $2 \times 2$ game furthest to the left constitutes a static Prisoner's Dilemma, but as the arms race proceeds the utility of additional armament declines and the game moves toward the right. When enough redundant, expensive, or destabilizing wea- pons are accumulated, the desirability of mutual arms reductions finally exceeds that of unilateral armament and the game is transformed from a Prisoner's Dilemma into a Perceptual Dilemma. In the course of such a transformation, however, each side's perceptions undoubtedly lag behind genuine changes in the other side's preferences. As Mikhail Gorbachev stated in 1985: 'Confidence cannot be restored at once. This is a difficult process. We were attentive to the American President's assurances that the US does not seek superiority and does not want a nuclear war. We sincerely hope that these statements will be borne out by deeds' (p. 1).

Unfortunately, even the best of deeds can be misinterpreted; cooperative actions carried out by one side are frequently overlooked or misconstrued by the other. Psychological research has shown that information which contradicts previous views is routinely discredited through biases in assimilation (cf. Lord et al., 1979) and that disconfirming evidence is typically undervalued relative to confirming evidence (Snyder \& Cantor, 1979; Wason, 1966). Research also suggests that positive behavior which violates prior expectations or comes from a disliked source tends to be explained as a result of situational demands, whereas positive behavior that confirms prior expectations or comes from a liked source is more often explained in terms of character (Holsti, 1969; Kulik, 1983; Regan et al., 1974). As a consequence, cooperative gestures made by an adversary seldom lead to large changes in how that adversary is perceived. Moreover, experimental game research has shown that competitively disposed parties to a conflict often have difficulty detecting a cooperative orientation held by the other side (Kelley \& Stahelski, 1970; Maki \& McClintock, 1983).

Yet even when cooperative initiatives are accurately detected, beliefs are usually slow to change. Laboratory research has shown that social perceptions can survive a complete discrediting of the information on which they were originally based, even in cases involving minimal initial evidence (Anderson et al., 1980). Several studies on 
Table XI. Half of a Supergame Including Prisoner's Dilemma and Perceptual Dilemma As Subgames

\begin{tabular}{cccccccccccc}
\hline & D & A & D & A & D & A & D & A & D & A \\
\hline D & $4,[6]$ & $-7,[7]$ & $5,[6]$ & $-7,[7]$ & $6,[6]$ & $-7,[7]$ & $7,[6]$ & $-7,[7]$ & $8,[6]$ & $-7,[7]$ \\
A & $5,[-7]$ & $-5,[-1]$ & $4,[-7]$ & $-5,[-1]$ & $3,[-7]$ & $-5,[-1]$ & $2,[-7]$ & $-5,[-1]$ & $1,[-7]$ & $-5,[-1]$ \\
\hline
\end{tabular}

As Row continues to choose 'D,' or disarmament, the game moves toward the left. As Row continues to choose 'A,' or armament, the game moves toward the right. The bracketed 'payoffs' for Column are Row's perceptions; in actuality, both participants operate from the position of Row. The matrix represents one of many possible supergames and is meant for purposes of illustration only.

judgement and decision-making have also demonstrated that people tend to change their prior positions more slowly than warranted by the evidence. According to Edwards (1968, p. 18): 'A convenient first approximation to the data would say that it takes anywhere from two to five observations to do one observation's worth of work in inducing a subject to change his opinions.'

Finally, misperceptions are reinforced within social and political communities. This factor is clear if the nuclear arms race is modeled not as a single supergame, but as a family of overlapping supergames in which each political leader is in a different location and is moving at a different speed (and possibly direction) within her or his supergame. Such a model would presumably result in the strengthening of commonly perceived elements. To take a simplified example, if at some point the United States were governed by two equally influential leaders, one whose perceptions conformed to a Perceptual Dilemma and one whose perceptions conformed to a Prisoner's Dilemma, then both leaders would at least agree that the Soviet Union preferred unilateral armament and that unilateral arms reductions by the United States must be avoided at all costs. Their disagreement over which alternative was best for the United States (mutual reductions or unilateral armament) would only come into play if the Soviet Union began to disarm, for it is only through an extended series of disarmament initiatives that either side can determine the other's preferences with confidence.

Of course, the foregoing is not to say that perceptions never change. Indeed, many superpower leaders seem increasingly aware that they share the same preference for mutual arms reductions (e.g. 'Transcript', 4 December 1989). Dramatic evidence of this shift came in June of 1992, when Presidents Bush and Yeltsin agreed to sweeping cuts in nuclear weapons. Yeltsin characterized the agreement as 'an expression of the fundamental change in the political and economic relations between the United States of America and Russia . . . achieved without deception, without anybody wishing to gain unilateral advantages' ('Excerpts', 17 June 1992). Thus, it is not that perceptions never change, but that perceptions rarely change as rapidly as the events that alter them. Viewed in this light, the Perceptual Dilemma may constitute nothing more than an extended transition between a previous Prisoner's Dilemma and an accurately perceived game of cooperation (i.e. a game in which both superpowers share the same preference for mutual disarmament).

\section{A Solution to the Perceptual Dilemma}

A recent laboratory study contrasted the effectiveness of cooperative initiatives in solving a Prisoner's Dilemma or a Perceptual Dilemma (Plous, 1987). In this research, participants believed that they were interacting with an adversary when in fact they played a nonzero-sum game against one of two computerized strategies: a strategy called 'Status Quo,' which matched subjects' responses from the previous trial, or a strategy called 'Disarmament Initiatives', which preceded matching with a period of unconditional cooperation. The results indicated that: (1) the Status Quo strategy led to 
competitive behavior, attitudes, and emotions in both the Prisoner's Dilemma and the Perceptual Dilemma; and (2) the Disarmament Initiatives strategy induced significantly more cooperation among parties locked in a Perceptual Dilemma than those in a Prisoner's Dilemma. Within a Prisoner's Dilemma, participants frequently exploited the Disarmament Initiatives strategy in order to secure their most preferred outcome (unilateral armament). In contrast, cooperative initiatives within a Perceptual Dilemma were reciprocated in all but one case, because mutual cooperation is the most preferred alternative in a Perceptual Dilemma.

The results from this experiment suggest that an optimal choice of strategy may depend critically upon the model that best approximates political reality. If either superpower prefers unilateral armament, then disarmament initiatives by the other entail a great deal of risk. On the other hand, if both sides genuinely seek mutual weapons reductions, then a clear, timelimited series of disarmament initiatives may be an individually and collectively optimal strategy. In the absence of unequivocal evidence supporting one model over another, political decision-makers must not only weigh the consequences of cutting weapons if the United States and Soviet Union are in a Prisoner's Dilemma, but the consequences of continuing to arm if the superpowers are in a Perceptual Dilemma.

Political leaders are thus in a 'metadilemma' in which their beliefs concerning arms race preferences are crossed with the actual preferences held by both sides. Given the high stakes involved and the difficulty in determining the other side's preferences with certainty, the historical trend has been to err on the side of 'conservatism' and assume that the other side does not desire mutual arms reductions. Yet the consequence of rendering this belief unfalsifiable is to immortalize the nuclear arms race. As Steinbruner (1979, p. 365) observed some time ago: 'The error of spurning a constructive lead is as serious as that of being gulled by cynical propaganda. In the current political atmosphere in the United States the probability of the former error appears to me to be greater.'

\section{NOTES}

1. For expository ease, 'Soviet Union' will here refer to the political entity that maintains control over Soviet nuclear weapons - whether the former USSR, the Commonwealth of Independent States, or some future governing authority.

2. There are several other serious limitations of $2 \times 2$ games such as the Prisoner's Dilemma, but it is not my purpose here to enumerate them. Rather, the question I wish to examine is more circumscribed: Within the constraints of a static $2 \times 2$ game, what is an appropriate model of the Soviet-US nuclear arms race? For a general discussion of the advantages and disadvantages of game-theoretic arms race models, see Anderton (1989), Brown (1986), Plous (1985), and Wagner (1985).

3. In the summer of 1985 , I was able to pilot test a Russian translation of the US Senate survey on 27 residents of Moscow and Leningrad. Although this sample of respondents cannot be taken as representative of Soviet leaders, it is worth noting that the pilot data conformed to the Soviet half of a Perceptual Dilemma. Soviet respondents viewed mutual arms reductions as by far the most desirable outcome for the Soviet Union $(M=+8.6$, compared with $M=-2.0$ for unilateral Soviet armament), and they saw unilateral Soviet reductions as the least desirable alternative $(M=-7.1)$. On the other hand, Soviet respondents felt that US leaders generally preferred unilateral US armament to mutual reductions $(M=+6.9$ versus $M=-5.8)$. In October, 1989, I was also able to administer a Russian translation of the survey to 17 Soviet leaders who had traveled to the United States for SovietUS talks (mainly politicians, policy advisors, and scholars affiliated with the Supreme Soviet, the Central Committee, the Ministry of Foreign Affairs, and the Academy of Sciences). In order to avoid social demand characteristics, I asked these respondents to complete the survey as they believed Leonid Brezhnev would have responded before he died in 1982. Although many of the leaders were quite critical of Brezhnev's tenure - one respondent described it as a 'senile autocracy' - mean responses conformed to the Soviet half of a Perceptual Dilemma. That is, respondents indicated that Brezhnev had preferred mutual arms reductions to unilateral armament but had perceived the United States as preferring superiority.

4. I am grateful to E. Margaret Newman for her skillful supervision of the survey, and to Professor C. P. Wendell Smith, Pro-Vice-Chancellor of the University of Tasmania, for hand-signing each of the 224 personalized cover letters. The cover letters were reproduced on the letterhead of the Pro-ViceChancellor and were accompanied by a three-page survey form, a postage-paid return envelope, and a self-addressed printed postcard for respondents to 
request a free copy of the survey results. The cover letters also guaranteed strict anonymity.

5. When examining the aggregate results, it is important to bear in mind that the ratings were made on an interval scale and that there is no problem-free way to average interval ratings across respondents. Aggregating desirability ratings is similar to averaging Fahrenheit and Celsius measures of temperature; higher numbers indicate greater heat, and much higher numbers indicate much greater heat, but an interpretation of the average heat between fifty degrees Fahrenheit and fifty degrees Celsius depends upon the conversion rule: $\mathrm{C}=5(\mathrm{~F}-32) / 9$. There is no conversion rule for averaging desirability ratings. Although the rating scale was bounded by -10 and +10 , and the centrepoint and endpoints of the scale were explicitly defined in the survey, it is probably the case that the scale was used differently from parliament member to parliament member. Average ratings must therefore be regarded only as approximations of the collective desirability of an alternative.

6. The cover letters accompanying each survey were printed in Hebrew and were personalized for each member of the Knesset. In addition, each survey packet included a pre-printed return envelope and a postcard for respondents to request a free copy of the survey results. Both the return envelope and the postcard were affixed with domestic Israeli postage and were pre-addressed to the 'International Legislative Attitudes Survey' in Tel Aviv. One month after the initial survey request was mailed, a telephone bank of Israeli volunteers contacted the offices of all non-respondents and a second set ot survey requests was sent out. Included in the second appeal were personalized, hand-signed endorsements of the project by Michael Inbar, Dean of Social Sciences at Hebrew University. For logistical support with the Israeli survey, I wish to express my deepest appreciation to Levy Zur, Lois Zur, Tamy Zur-Weisman, Daniella Horav, Michael Inbar, Sheizaf Rafaeli, Anat Rafaeli, John W. Lewis, Robert L. Street, and Jonathon Katznelson.

7. Some further comparisons: $87 \%$ of the respondents were male, compared with $92 \%$ of the Knesset as a whole. The mean age of respondents was 54 years $(\mathrm{SD}=8.6)$, compared with an average age of 55 for the entire Knesset $(\mathrm{SD}=8.7)$. Fifty-six percent of the sample was born in Israel and $94 \%$ spoke English, compared with figures of $61 \%$ and $86 \%$ respectively for the full Knesset. Thirteen percent of the respondents were ministers, $3 \%$ were deputy ministers, and $28 \%$ held other leadership positions (e.g. chair of a committee), compared to $21 \%, 4 \%$, and $22 \%$ for the Knesset in general. Finally, $31 \%$ of the respondents were members of the Foreign Affairs and Defense Committee, compared with $24 \%$ of the total Knesset. When considered together, these statistics suggest that the 33 Knesset members who completed a survey were not substantially different from the 87 Knesset members who did not.

8. Recent pilot data from the People's Republic of China also provide support for a Perceptual
Dilemma. During the summer of 1988, a survey similar to the Australian and Israeli surveys was administered to 40 college graduates from major cities throughout China. The respondents viewed both superpowers as preferring mutual reductions to unilateral armament - though only by a slim margin - and they perceived Soviet leaders as somewhat more desirous of mutual reductions and more opposed to an arms race than US leaders. Despite poor relations between China and the Soviet Union since the Sino-Soviet split, Chinese respondents also preferred mutual reductions $(M=+7.8)$ to unilateral US armament $(M=-1.4)$ and even slightly preferred unilateral Soviet armament $(M=-4.1)$ to a continuation of the Soviet-US nuclear arms race $(M=-5.3 ; n s$ by $t$-test). I am indebted to Harry C. Triandis for arranging the translation and distribution of this survey.

\section{REFERENCES}

Adelman, Kenneth L., 1988. 'On the Press: Terrific, Outrageous, Unfair', Deadline: $A$ Bulletin From the Center for War, Peace, and the News Media, vol. 3, March/April, pp. 3-6.

Anderson, Craig A; Mark R. Lepper \& Lee Ross, 1980. 'Perseverance of Social Theories: The Role of Explanation in the Persistence of Discredited Information', Journal of Personality and Social Psychology, vol. 39, no. 6, June, pp. 1037-1049.

Anderton, Charles H., 1989. 'Arms Race Modeling: Problems and Prospects', Journal of Conflict Resolution, vol. 33, no. 2, pp. 346-367.

Axelrod, Robert \& William Zimmerman, 1981. 'The Soviet Press on Soviet Foreign Policy: A Usually Reliable Source', British Journal of Political Science, vol. 11, part 2, April, pp. 183-200.

Bennett, P. G. \& M. R. Dando, 1983. 'The Arms Race: Is It Just a Mistake?', New Scientist, vol. 97, no. 1345,17 February, pp. 432-435.

Beres, René, 1982. 'Myths and Realities: US Nuclear Strategy', Occasional Paper no. 32. Muscatine, IA: The Stanley Foundation.

Bialer, Seweryn \& Joan Afferica, 1982/1983. 'Reagan and Russia', Foreign Affairs, vol. 61, no. 2, Winter, pp. 249-271.

Bradley, Omar, 1949. 'This Way Lies Peace', Saturday Evening Post, 15 October, pp. 33, 168-70.

Brams, Steven J., 1985. Superpower Games: Applying Game Theory to Superpower Conflict. New Haven, CT: Yale University Press.

Brams, Steven J. \& D. Marc Kilgour, 1988. Game Theory and National Security. New York: Basil Blackwell.

Brew, J. S., 1973. 'An Altruism Parameter for the Prisoner's Dilemma', Journal of Conflict Resolution, vol. 17 , no. 2, June, pp. 351-367.

Brown, Scott, 1986. 'The Superpowers' Dilemma', Negotiation Journal, vol. 2, no. 4, October, pp. 371384 . 
Bykov, Oleg, 1980. 'The Imperatives of Military Detente', pp. 127-137 in N. N. Inozemtsev, ed., Peace and Disarmament: Academic Studies. Moscow: Progress.

Caldwell, Lawrence T. \& Robert Legvold, 1983. 'Reagan Through Soviet Eyes', Foreign Policy, vol. 52, Fall, pp. 3-21.

Daniel, Donald C., ed., 1978. International Perceptions of the Superpower Military Balance. New York: Praeger.

$\rightarrow$ Deutsch, Morton; Yakov Epstein, Donnah Canavan \& Peter Gumpert, 1967. 'Strategies of Inducing Cooperation: An Experimental Study', Journal of Conflict Resolution, vol. 11, no. 3, September, pp. 345-360.

Edwards, Ward, 1968. 'Conservatism in Human Information Processing', pp. 17-52 in Benjamin Kleinmuntz, ed., Formal Representation of Human Judgment. New York: Wiley.

Excerpts from Bush's Address on Foreign Policy at Coast Guard Academy, 1989. New York Times, 25 May, p. 4.

Excerpts from Bush-Yeltsin Conference: Working Toward a Safer World, 1992. New York Times, 17 June, p. A10.

Flynn, Gregory \& Hans Rattinger, eds, 1985. The Public and Atlantic Defense. Totowa, NJ: Rowman \& Allanheld.

Foreign Relations of the United States: 1949 (Volume I), 1976. Washington, DC: US Government Printing Office.

Foreign Relations of the United States: 1951 (Volume I), 1979. Washington, DC: US Government Printing Office.

Frei, Daniel, 1986. Perceived Images: US and Soviet Assumptions and Perceptions in Disarmament. Totowa, NJ: Rowman \& Allanheld.

$\rightarrow$ Garthoff, Raymond L., 1978. 'Mutual Deterrence and Strategic Arms Limitations in Soviet Policy', International Security, vol. 3, no. 1, Summer, pp. 112147.

Goldinger, Carolyn, ed., 1983. Historic Documents oj $\rightarrow$ 1982. Washington, DC: Congressional Quarterly.

Gorbachev, Mikhail S., 1985. 'Gorbachev's PostSummit Press Conference', The Current Digest of the Soviet Press, 18 December, pp. 10-16.

Gordon, Michael R., 1987. 'Soviet Said to Lead US ir $\rightarrow$ Lumsden, Malvern, 1966. 'Perception and Information Image for Arms Cuts', New York Times, 7 June, p. 16.

Guroff, Gregory \& Steven Grant, 1981. 'Soviet Elites $\rightarrow$ World View and Perceptions of the US', USICA Report no. R-18-81. Washington, DC: Offices of Research, United States International Communication Agency.

Halloran, Richard, 1988. 'Army Office Gleans Soviet Military's Open Secrets', New York Times, 13 March, p. 12.

$\rightarrow$ Hardin, Russell, 1983. 'Unilateral Versus Mutual Disarmament', Philosophy \& Public Affairs, vol. 12, no. 3, April, pp. 236-254.

Hasegawa, Tsuyoshi, 1986. 'Soviets on Nuclear-warfighting', Problems of Communism, vol. 35, no. 4, July/August, pp. 68-79. July/August, pp. 68-79.
Hermann, Margaret G., 1980. 'Assessing the Person $\rightarrow$ McConnell, James Mo. 2, Spring, pp. 10-17. alities of Soviet Politburo Members', Personality and Social Psychology Bulletin, vol. 6, no. 3, September, pp. 332-352.

Holloway, David, 1984. The Soviet Union and the Arms Race. New Haven, CT: Yale University Press.

Holsti, Ole R., 1969. 'The Belief System and National Images: A Case Study', pp. 543-550 in James N. Rosenau, ed., International Politics and Foreign Policy. New York: Free Press.

Ifft, Ed, 1986. 'Status and Prospects of the Negotiation', Presentation at the Center for International Security and Arms Control, Stanford University, California.

Jackson, William D., 1981. 'Soviet Images of the US As Nuclear Adversary 1969-1979', World Politics, vol. 33, no. 4, July, pp. 614-638.

Jervis, Robert, 1976. Perception and Misperception in International Politics. Princeton, NJ: Princeton University Press.

Kelley, Harold H. \& Anthony J. Stahelski, 1970. 'Social Interaction Basis of Cooperators' and Competitors' Beliefs About Others', Journal of Personality and Social Psychology, vol. 16, no. 1, January, pp. 66-91.

Kulik, James A., 1983. 'Confirmatory Attribution and the Perpetuation of Social Beliefs', Journal of Personality and Social Psychology, vol. 44, no. 6, June, pp. 1171-1181.

Lebedev, Yuri, 1986. 'Military and Strategic Parity and the Realities of the Nuclear and Space Age', International Affairs, no. 7, July, pp. 23-28.

Lindskold, Svenn; Thomas V. Bonoma, Barry R. Schlenker \& James T. Tedeschi, 1972. 'Factors Affecting the Effectiveness of Reward Power', Psychonomic Science, vol. 26, no. 2, pp. 68-70.

Lord, Charles G.; Lee Ross \& Mark R. Lepper, 1979. 'Biased Assimilation and Attitude Polarization: The Effects of Prior Theories on Subsequently Considered Evidence', Journal of Personality and Social Psychology, vol. 37, no. 11, July, pp. 2098-2109.

Luce, R. Duncan \& Ernest W. Adams, 1956. 'The Determination of Subjective Characteristic Functions in Games With Misperceived Payoff Functions', Econometrica, vol. 24, no. 2, April, pp. 158171 in Strategic Thinking', Journal of Peace Research, vol. 3, no. 3, pp. 257-277.

Lumsden, Malvern, 1973. 'The Cyprus Conflict as a Prisoner's Dilemma Game', Journal of Conflict Resolution, vol. 17, no. 1, March, pp. 7-31.

Luzin, Nikolai, 1981. Nuclear Strategy and Common Sense. Moscow: Progress.

Maki, Judith E. \& Charles G. McClintock, 1983. 'The Accuracy of Social Value Prediction: Actor and Observer Influences', Journal of Personality and Social Psychology, vol. 45, no. 4, April, pp. 829-838.

Markham, James M., 1987. 'Gorbachev Gains in West Germany', New York Times, 17 May, p. 6.

MccGwire, Michael, 1987. 'Why the Soviets are Serious About Arms Control', The Brookings 
the Proper Focus of Military Development', World Politics, vol. 37, no. 3, April, pp. 317-343.

Platonov, Alexei, 1986. A Dangerous Step. Moscow: Novosti Press Agency.

$\rightarrow$ Plous, S., 1985. 'Perceptual Illusions and Military Realities: A Social-Psychological Analysis of the Nuclear Arms Race', Journal of Conflict Resolution, vol. 29, no. 3, September, pp. 363-389.

$\rightarrow$ Plous, S., 1987. 'Perceptual Illusions and Military Realities: Results from a Computer-Generated Arms Race', Journal of Conflict Resolution, vol. 31, no. 1, March, pp. 5-33.

$\rightarrow$ Plous, S., 1988. 'Modeling the Nuclear Arms Race as a Perceptual Dilemma', Philosophy \& Public Affairs, vol. 17 , no. 1 , Winter, pp. 44-53.

Ponomarev, Boris, 1985. Winning for Peace: The Great Victory - Its World Impact. Moscow: Progress.

Power, Thomas S., 1965. Design for Survival. New York: Coward-McCann.

Pruitt, Dean G., 1967. 'Reward Structure and Cooperation: The Decomposed Prisoner's Dilemma Game', Journal of Personality and Social Psychology, vol. 7, no. 1, January, pp. 21-27.

Pruitt, Dean G., 1970. 'Motivational Processes in the Decomposed Prisoner's Dilemma Game', Journal of Personality and Social Psychology, vol. 14, no. 3, March, pp. 227-233.

Regan, Dennis T.; Ellen Straus \& Russell Fazio, 1974. 'Liking and the Attribution Process', Journal of Experimental Social Psychology, vol. 10, no. 4, July, pp. 385-397.

$\rightarrow$ Scodel, Alvin, 1962. 'Induced Collaboration in Some Non-Zero-Sum Games', Journal of Conflict Resolution, vol. 6, no. 4, December, pp. 335-340.

$\rightarrow$ Shubik, Martin, 1968. 'On the Study of Disarmamen and Escalation', Journal of Conflict Resolution, vol. 12 , no. 1, March, pp. 83-101.

Snyder, Mark \& Nancy Cantor, 1979. 'Testing Hypoth- eses About Other People: The Use of Historical Knowledge', Journal of Experimental Social Psychology, vol. 15, no. 4, July, pp. 330-342.

Steinbruner, John, 1979. 'US Senate Testimony', pp. 363-366 of Perceptions: Relations Between the United States and the Soviet Union (United States Senate Committee on Foreign Relations). Washington, DC: Government Printing Office.

Talbott, Strobe, 1984. The Russians and Reagan. New York: Vintage.

Tetlock, Philip E., 1985. 'Integrative Complexity of American and Soviet Foreign Policy Rhetoric: A Time-Series Analysis', Journal of Personality and Social Psychology, vol. 49, no. 6, June, pp. 15651585.

Transcript of Bush's News Conference After the Malta Talks, 1989. New York Times, 4 December, p. 11.

Transcript of Bush's Remarks on Transforming SovietAmerican Relations, 1989. New York Times, 13 May, p. 4.

Trofimenko, Genrikh, 1986. The US Military Doctrine. Moscow: Progress.

Wagner, R. Harrison, 1985. 'The Theory of Games and the Problem of International Cooperation', American Political Science Review, vol. 77, no. 1, March/ June, pp. 330-346.

Wason, Peter C., 1966. 'Reasoning', pp. 135-151 in Brian M. Foss, ed., New Horizons in Psychology. Harmondsworth, Middlesex: Penguin.

Weeks, Albert L. \& William C. Bodie, eds, 1983. War and Peace: Soviet Russia Speaks. New York: National Strategy Information Center.

Zagladin, Vadim, 1986. Our Aim: Universal International Security. Moscow: Novosti Press Agency.

Zimmerman, William \& Glenn Palmer, 1983. 'Words and Deeds in Soviet Foreign Policy: The Case of Soviet Military Expenditures', American Political Science Review, vol. 77, no. 2, June, pp. 358-367.

S. PLOUS, b. 1959, PhD in Psychology (Stanford University); SSRC-MacArthur Foundation Fellow in International Peace and Cooperation (1986-88); Visiting Assistant Professor, University of Illinois (1988-90); Assistant Professor, Wesleyan University (1990- ); recent book: The Psychology of Judgment and Decision Making (McGraw-Hill, 1993). 